\title{
INVESTIGATING \\ THE INVESTIGATORS
}

\section{A summary of the Khampepe Commission of Inquiry}

\begin{abstract}
Andrew Kanyegirire
Institute for Security Studies

akanyegirire@issafrica.org
\end{abstract}

\begin{abstract}
The D irectorate of Special O perations (DSO) was set up in 1999 as a specialised unit of the National
Prosecuting Authority with the dual responsibility of investigating and prosecuting national priority crimes, the main focus being high-level corruption and organised crime. D espite its successes, by 2005 critics were raising questions about its mandate and the strained relationship between the DSO and the South African Police
\end{abstract} Service (SAPS). Consequently, President M beki appointed Judge Sisi Khampepe to head a Commission of Inquiry into the mandate and location of the DSO. This article is a summary of some of the key issues raised in the Khampepe Report.

$\mathrm{T}$ he Directorate of Special O perations (D SO) was established in 1999 with the specific responsibility to investigate and prosecute cases of organised crime and corruption. The DSO, also known as the Scorpions, was located in the National Prosecuting Authority (N PA) to allow for prosecutor-led investigations. Within no time the Scorpions were involved in a number of high-level investigations involving the political and economic elite of South Africa. The perceived success of their investigations, particularly against high-ranking public officials, brought them a measure of public support. However, repeated media leaks about their investigations and allegations of abuse of power in the exercise of search warrants (particularly in the Jacob Zuma case), led to criticism from politicians who felt that the Scorpions were being used to influence the outcome of the power struggle between President Thabo M beki and Zuma in the ANC.

In 2005 the legality of the Scorpions' mandate was called into question and problems were raised about the apparently strained relationship between the
DSO and the South African Police Service (SAPS). To avoid further political and legal rows concerning the DSO, President M beki appointed Judge Sisi Khampepe on 1 April 2005 to head a Commission of Inquiry to 'inquire into, make findings, report on and make recommendations' regarding the mandate and location of the DSO.

In June 2006 President M beki and his Cabinet adopted the recommendations of the Khampepe Commission, but the report was only made public almost two years later, in May 2008, soon after Cabinet had endorsed draft laws to dissolve the Scorpions and have them integrated into the SAPS. These Bills reflected the ANC's decision to dismantle the Scorpions, as was agreed by the party at its 2007 Polokwane Conference.

\section{The concerns of the Commission}

The Khampepe Commission of Inquiry was established to respond to concerns and questions relating to the role and functioning of the DSO that had been raised by the public, components of the 
criminal justice system and from the intelligence community. As outlined in the Khampepe

Commission Report, these concerns related to:

(a) the perceived institutional nightmare of the DSO mandate to:

(i) investigate and to carry out any function incidental thereto;

(ii) gather, keep and analyse information; and

(iii) institute criminal proceedings, relating to offences or unlawful activities committed in an organised fashion...

(b) the jurisprudential soundness of housing the investigative and prosecutorial capacities of the DSO in one structure under the authority of the National Director of Public Prosecution (NDPP), with the minister for justice and constitutional development exercising final political responsibility over the DSO.

(c) the overlapping mandates of the DSO and the SAPS with regard to the investigation of national priority crimes, including organised crime and the duplication of resources resulting there-from.

(d) the existence within the DSO of an information [intelligence] gathering capacity that functions outside the legislative framew ork of the designated intelligence structures, the uncertainty and the exclusion of the DSO from the Intelligence oversight Act, 40 of 1994, thereby making its intelligence activities not subject to the oversight functions of the Inspector $\mathrm{G}$ eneral of Intelligence and the joint standing committee on intelligence.

(e) lack of coordination and cooperation between the DSO on the one part, the SAPS and the designated intelligence structures, such as the NIA and the SASS on the other.

(f) the location of the DSO within the National Prosecuting Authority and consequently under the Department of Justice, which was argued to be in conflict with the provisions of the Constitution. The amalgamation of both law enforcement (policing) as well as justice (prosecuting) elements in the DSO were exacerbated due to the competition over jurisdictional territory and the concurrence of mandates.
The Commission was tasked with the responsibility of obtaining clarification on the location, mandate and operation of the DSO vis-à-vis other relevant government departments or institutions (Khampepe 2006: 6-7).

\section{Selected extracts}

It is against this background that the Khampepe report presents an overview, findings and recommendations on eleven key issues. These are:

1. The rationale for the establishment of the DSO

2. The legislative mandate of the DSO

3. Systems for management and control of the DSO

4. Systems for communication of the DSO

5. O versight and accountability in respect of intelligence and related operations of the DSO

6. Constitutional and legislative mandates of the SAPS

7. Systems for co-ordination and co-operation betw een the SAPS, intelligence agencies and the DSO

8. The effectiveness and efficiency of co-ordination of intelligence: DSO/SAPS/N IA

9. The efficacy of co-ordinating systems that exist between the intelligence agencies

10. Training or further training on policing or investigating methods

11 The impact of locating investigators and prosecutors within the $\mathrm{N}$ ational Prosecuting Authority

As will be highlighted in the summaries that follow, one of the key themes that cuts across the report concerns the presence, or not, of links between the work of the DSO and SAPS in the fight against crime. The article will focus on selected aspects of the report that best explain the position of the Commission with regard to the location, mandate and operation of the DSO .

\section{The rationale for the establishment of the DSO}

The Khampepe Commission report highlights four principal reasons behind the establishment of the DSO. These are the perceived incapacity of the SAPS to investigate high-level priority crimes, the need to develop a multi-disciplinary approach in the fight against corruption, the need to establish an entity that would be able to attract and retain highly skilled personnel, and lastly, the perceived 
illegitimacy of the SAPS for historical and political reasons. After careful consideration of the information, evidence and arguments concerning the establishment of the DSO, the report concludes by arguing that the rationale for the establishment of the DSO is as valid today as it was at conception (Khampepe 2006:24).

\section{The legislative mandate of the DSO}

Section 12 of the report examines the legislative mandate of the DSO. The findings clarify and provide justifications for the DSO 's legal mandate to investigate and prosecute serious crimes within the parameters of a single entity. Sub-section 12.1 states:

The argument that the legal mandate of the DSO to investigate and prosecute serious organised crime is unconstitutional within the meaning of section 199(1) of the Constitution is without merit. It is clear from the reading of the constitutional judgment in the Minister of Defence v Potsane 2002 (1) SA 1 (CC), at p.14, para 26 that the meaning of 'single' ... conveys no more than the fact that various police forces that used to form part of the 'independent' homelands ... would be amalgamated into one single police force. The word 'single' does not therefore connote 'exclusive' (Khampepe 2006:38).

The report highlights the fact that the legislature intentionally drafted the legal mandate of the DSO to be wide and argues that this was prudent. This is based on the fact that organised crime syndicates are not only pervasive, but that they are also are highly sophisticated and command huge financial resources that enable them to mount heavyweight legal defences with a view to resisting prosecutions and/or convictions. (Khampepe 2006:39). Khampepe argues that an overly prescriptive legal mandate would have led to constant judicial attacks and would have frustrated the DSO's ability to fulfill its mandate.

The report goes on to insist that 'there is nothing impermissible in law to draft the legal mandate of the DSO to be as broad as it appears in the NPA Act' (Khampepe 2006:40). In addition, the report argues that there is nothing unconstitutional in the DSO sharing the mandate to tackle organised crime with the SAPS, but acknowledges that the proper management of tensions that may arise from a shared mandate is a challenge.

However, the report does raise concerns about the conduct of the DSO. Based on evidence and arguments made before the Commission, the report reveals that the implementation of the legal mandate of the DSO was not entirely satisfactory. In particular, the leaking of information to the media was identified as a problem. The report notes that when the subject matter of DSO investigations is published it can lead to the prejudice of the persons under investigation. Besides indicating an abuse of power by the DSO, this may also point to a possible violation of the rights and freedoms protected under the Bill of Rights (Khampepe 2006:11). Here the Commission found that the DSO tended to go beyond its 'information' gathering mandate to include intelligence gathering (also see section 24 below).

In an attempt to come to terms with some of the scathing criticisms that have been levelled against the DSO, section 15 (Findings in relation to the evaluation of the implementation of the legislative mandate of the DSO ) suggests that this might be because the DSO is better resourced than the SAPS and also has the 'unfair' advantage of being able to select cases for its investigations. The Commission believed that this gave rise to a competitive environment and caused conflict and tensions between the DSO and the SAPS.

The Commission critically questioned the role of the Ministerial Co-ordinating Committee (MCC) which was intended (in the NPA Act) to address a number of issues relating to the functioning of the DSO . Sub-section 15.1 points out that the MCC did not properly discharge its responsibility under the Act and that it therefore also failed to avert or mitigate some of the problems between the SAPS and the DSO . Sub-section 15.3 states that the resistance by both DSO investigators and prosecutors to relocate to the SAPS was suggestive of a lack of shared objective amongst officials of the law enforcement agencies to perform their functions in fighting crime, irrespective of where a particular institution is located. This compares poorly to other countries where various entities that fight organised crime 
share legal mandates and strategies to tackle certain crimes.

\section{SO systems for communication}

In section 22 ('Recommendations in relation to the systems for communication of the DSO ') the Commission argued that 'it cannot be overemphasised that the DSO as a law enforcement agency and an organ of state is constitutionally bound to act within the law. It is enjoined by the Bill of Rights to respect the rights of every person, including those who may fall within its target (sting) of investigation or prosecution' (Khampepe 2006:61). The key issue to bear in mind here is that the Scorpions needed to discharge their responsibilities within the parameters of the Constitution and with due regard to the Bill of Rights.

\section{0 versight and accountability in respect of the intelligence and related operations of the DSO} Issues concerning the oversight and accountability in respect of the intelligence and related operations of the DSO are for the most part dealt with in Sections 23 to 25 . The Commission found that, although the DSO is mandated to gather, keep and analyse information as is conferred upon it in terms of section 7(1) (a) (ii) of the NPA Act, the bulk of the evidence before the Commission as well as the onsite visits to the DSO tended to show that the DSO had established intelligence gathering capabilities. The report states that 'this goes beyond the ambit of its information-gathering mandate set out in section 7 of the N PA Act' (Khampepe 2006:66-67) and would be in conflict with the Constitution.

The report deals with the disjunction in political accountability for the work of the DSO between the Minister for Justice and Constitutional Development and the Minister of Safety and Security (Khampepe 2006: 61-73). It noted that although the Minister for Justice and Constitutional Development exercises final responsibility over the work of the NPA, she does not have practical, effective political oversight in respect of the law enforcement work of the DSO. The M inister of Safety and Security exercises final responsibility for law enforcement, yet he does not have political responsibility in respect of the investigative work of the DSO.
It is in this regard that section 25

('Recommendations in relation to the oversight and accountability of the intelligence operations of the DSO') goes on to:

- Insist on the harmonisation of the 'political oversight over the activities of the DSO'

- Remind us of the 'inherent need for all law enforcement agencies to have a joint purpose in addressing all law enforcement responsibilities... The tensions that bedevil the relationship of the DSO and the SAPS are incompatible with the constitutional responsibilities of these institutions. It is critical that these institutions answer positively to the constitutional mandate for co-operative governance required of all organs of state'

- Call upon the President to exercise 'the power conferred on him in terms of section 97 (b) of the Constitution to transfer the power or function entrusted to the Minister for Justice and Constitutional Development by the N PA Act to the Minister of Safety and Security thereby vesting political authority over the law enforcement component of the DSO in the Minister of Safety and Security'.

- Caution that 'the DSO should act within the parameters of its legislative mandate and not impinge on the territory constitutionally assigned to other entities'

- Call for 'greater co-operation and interdependence as well as enhanced skills and expertise between and among the law enforcement agencies'

- Call for a legislative overhaul of the disjunction in political accountability over the DSO. Again the emphasis is that the President can rectify it in terms of section $97(\mathrm{~b})$ of the constitution.

(Khampepe 2006:71-73)

\section{Systems for co-ordination and co-operation} between SAPS, intelligence agencies and the DSO Sections 30-31 of the report deal with the findings and recommendations concerning the systems for co-ordination and operation between the SAPS, intelligence agencies and the DSO. Here it becomes evident that there were no systems of co-ordination and co-operation between the DSO and the SAPS. The report recommends that the DSO should form part of the family of law enforcement structures and 
share expertise and information for an overall effective crime combating strategy.

\section{Training or further training on policing or investigating methods}

The Commission's concerns over the absence of cooperation and co-ordination between the DSO and SAPS find further expression in sections 39 and 40 that deal with issues of training. In accordance with proponents of the view that the DSO has been far better resourced than the SAPS, the report argues that the Commercial O rganised Crime U nit of the SAPS, which has related responsibilities, should be furnished with the same equipment, resources and legal powers in order to emulate the successes of the DSO. The report goes on to state that, given the lack of effective cooperation between and coordination of the activities of the DSO and the SAPS, it is inescapable that there may be duplication in the resources both institutions channel towards training. The recommendation here is that 'the DSO and the SAPS streamline the training of their personnel to achieve greater efficiencies' (Khampepe 2006:92).

\section{Location of investigators and prosecutors within the NPA}

As previously indicated in this summary of the Khampepe Commission Report, it is evident that one of the contentious issues that has characterised the debate on the Scorpions includes the location of investigators and prosecutors within the NPA. O pponents of this - including the SAPS - have argued that it is unsound to locate investigators and prosecutors under one roof. The logical conclusion to this would be that prosecutors should remain within the prosecuting authority and the law enforcement officers redeployed back to the SAPS (Khampepe 2006:93). The argument apparently hinged on the assumption that the presence of prosecutors and investigators under one roof could compromise the activities of the prosecutors.

Despite this, the report draws attention to the use of multi-disciplinary structures, that is, having prosecutors, intelligence operatives or analysts as well as investigators in a team, in foreign jurisdictions. In countries such as the USA, multidisciplinary structures ('Strike Forces') are created for specific purposes with various elements within it reporting to their respective authorities. The report also provides the examples of England and Wales, where the Serious O rganised Crime Agency is a multi-disciplinary structure yet does not fall under the Crown Prosecution Service.

Although the report notes concerns that the inclusion of prosecutors in the DSO investigating teams could compromise their independence it nevertheless argues that the various disciplines within the DSO should remain under a single command structure. This is based on the view that the structure of the DSO enhances closer cooperation among the various disciplines, as the prosecutors and the investigators benefit from one another's expertise, thereby making crosspollination an effective strategy in combating crime and returning higher conviction ratios.

\section{Location of the DSO}

With regard to the specific location of the DSO, section 45 of the Report lists those entities or relevant individuals that either supported or opposed the current location of the DSO. Those in favour included:

- The M inister for Intelligence Services

- The Inspector General of Intelligence

- National Intelligence Coordinating Committee (NICOC)

- The Institute of Security Studies

- The Foundation for Human Rights

- Prof. Kader Asmal

- Ms Fatima Chohan

- The DSO

Those in the opposing camp who called for the translocation of the DSO to the SAPS included the SAPS and the National Intelligence Agency (NIA).

The recommendations in section 47 regarding the question of the location of the DSO argue that 'the rationale for locating the DSO under the NDPP and the M inister for Justice and Constitutional Development in 2002 still pertains' (Khampepe 2006:103-104). This was based both on the existence of other investigative directorates (Independent Directorate: Serious Economic $O$ ffences and Independent Directorate: O rganised Crime) under the N PA and because DSO 
investigations were to be prosecution-led, thus it could only be located within the prosecuting authority, which constitutionally is authorised to institute prosecutions.

However, the report draws attention to the fact that (sub-section 47.3) the SAPS and the DSO still did not appreciate the legal imperative for co-operation. The Commission called for decisive executive action to compel a realignment of attitudes by these institutions. O ne of these actions would be to transfer political oversight and responsibility over to the law enforcement component of the DSO to the M inister of Safety and Security. Still the Commission insisted that the DSO should continue to be located within the NPA.

\section{Conclusion}

The Report of the Khampepe Commission of Inquiry into the mandate of the Directorate of Special O perations concludes with the following key four points, contained in sections 53, 54, 55 and 56 respectively (Khampepe 2006:112):

- The inexorable quest for an effective and efficient strategy to tackle organised crime must run like a golden thread through the whole tapestry of the law enforcement/prosecutorial and intelligence structures. The attainment and maintenance of that efficacy is dependent on the law enforcement/prosecutorial structures cooperating and coordinating their activities closely with one another as well as with the requisite statutory intelligence structures.

- The imperfections in the inter-relationship of the law enforcement structures including the relationship of the DSO with such structures giving rise to the establishment of the Commission derive largely to operational matters. It is necessary therefore to create - on an ongoing basis - a review mechanism to manage the constant challenges that may arise in the execution of the work of these structures.

- The report deals with various aspects that would require the Legislature's consideration to give effect to these recommendations and to harmonise the implementation of these recommendations. Parliament will have to give effect to these recommendations and harmonise their implementation with existing legal provisions of the relevant pieces of legislations and government policies.

- The threat that organised crime presents to the democratic institutions and economic integrity of the country poses a formidable challenge that will continually require creative and determined strategies to address. These strategies will include, by definition, enhanced co-operation among the various law enforcement structures whose primary constitutional responsibility it is to secure the country and its people.

\section{References}

Blandy, F 2005. Khampepe: Leadership must walk the same walk. Mail and Guardian 0 nline 130 ctober. Available at http://www.mg.co.za/articlePage.aspx?article $\mathrm{id}=253635 \&$ \&rea=/breaking_news/breaking_news national/ [accessed 21 May 2008].

Khampepe Commission of Inquiry into the Mandate and Location of the Directorate of Special O perations ("The DSO "). Final Report. February 2006. Available at http://www.info.gov.za/view/D ownloadFileAction?id= 80441 [accessed 12 May 2008].

Mail and Guardian 2001. Yengeni summoned to explain assets. Mail and Guardian O nline 20 April. Available at http://www.armsdeal-vpo.co.za/articles00/explain_ assets.html [accessed 21 May 2008].

wa ka N gobeni, W 2004. N gcuka under new fire. Mail and Guardian O nline 21 May. Available at http://www.armsdeal-vpo.co.za/articles06/new_fire.html [accessed 21 May 2008].

Xundu, X and wa ka N gobeni, W 2005. Scorpions a security risk. Sunday Times 0 nline 90 ctober. Available at http://www.armsdeal-vpo.co.za/articles08/ security_risk.html [accessed 21 May 2008]. 